\title{
BIBLIOGRAPHY
}

\section{Note on sources}

During my research, I spoke with several interviewees who preferred to remain anonymous. I was also allowed to see material that is not open to public access. I have cited information gained from these interviews and this material as 'private information' or 'private collection'. The private collection cited has no connection with any person named in the text.

\section{Archival sources}

Britain

Cambridge University South Asian Archive

Arthur Papers

Bell Papers

Benthall Papers

Brendon Memoirs

Collier Papers

Cowley Memoirs

Darling (M. L.) Papers

Dash Memoirs

Derrick-Jehu and Somerset Papers

Goodman Papers

Heaney Papers

Holland Memoirs

Hubback Memoirs

Hudson (H. B.) Papers

Hume Papers

MacNabb Memoirs

Medd Papers

Perry-Keene Memoirs

Reynolds Papers

Somerset Memoirs

Spate Papers

Stephens Papers

Talbot Papers

Taylor (S. G.) Memoirs

Tennyson Papers 


\section{BIBLIOGRAPHY}

India Office Library, British Library (London)

India Office Records (IOR)

$\mathrm{L} / \mathrm{MIL} / 17 / 5$

$\mathrm{L} / \mathrm{P} \& \mathrm{~J} / 8 / 663$

$\mathrm{L} / \mathrm{P} \& \mathrm{~J} / 10 / 117$

$\mathrm{L} / \mathrm{P} \& \mathrm{~J} / 10 / 118$

$\mathrm{L} / \mathrm{P} \& / 10 / 119$

$\mathrm{R} / 3 / 1 / 157$

$\mathrm{R} / 3 / 1 / 176$

$\mathrm{V} / 27 / 314 / 573$

$\mathrm{Y} / 101, \mathrm{Y} / 104$

Private Papers

Mss Eur A 221 (Jenkins Papers)

Mss Eur C 645 (Jenkins-Abbott Correspondence)

Mss Eur D 718 (Christie Diary)

Mss Eur D 807 (Jenkins Papers)

Mss Eur F 164 (Mudie Papers)

Mss Eur Photo Eur 279 (Zafrullah Khan Memoirs)

Mss Eur R 150 (Beaumont Interview)

Liddell Hart Centre for Military Archives (King's College London) (LHA)

Ismay Papers

National Archives of the United Kingdom (Kew) (TNA)

$\mathrm{CAB} 127$

CAB 128

Rhodes House Library (Oxford University)

Coupland Papers

University of Southampton Libraries Special Collections

Mountbatten Papers

\section{India}

Nehru Memorial Museum and Library (New Delhi) (NMML)

All India Congress Committee Papers

Hindu Mahasabha Papers

Mahajan (M. C.) Papers

Nehru (Rameshwari) Papers

National Archives of India (New Delhi) (NAI)

Government records

Legislative

Reference 1948 


\section{BIBLIOGRAPHY}

Reform 1947

Ministry of External Affairs [MEA] and Commonwealth Relations

OS (I, III, V) 1947, 1948

Pakistan (I) 1948

Ministry of Home Affairs

H 1948

RH 1953

RHB 1949, 1950

Political Department/Ministry of States

G(R) 1949

IA (States) 1947

IB 1947

K 1948, 1951, 1952

P 1949

PA 1951

PR 1947

R 1949

Private papers

Patel Papers

Prasad (Rajendra) Papers

\section{Pakistan}

National Archives of Pakistan (Islamabad)

S-415: Police Abstract of Intelligence 1947

Punjab Provincial Archives (Lahore) (PPA)

Civil Defence 1951

Food Supplies 1948, 1949, 1951

Home 1953

Home/Gazette 1947, 1950, 1951

Home/General 1947, 1950, 1952, 1954, 1955

Home/Judicial and Jails 1947, 1948, 1949, 1950

Home/Military 1951

Home/Passport 1947, 1949

Home/Police 1947, 1951

Home/Police and Military 1948

Industries 1947, 1951

Judicial and Jails 1951

Medical 1949, 1950, 1951

Passport 1949, 1951

Public (Health) 1949 


\section{BIBLIOGRAPHY}

\section{United States}

Stanford University Libraries (Palo Alto)

Central Map Collection

\section{Other unpublished primary sources}

Documents remaining in their authors' possession

Beaumont, Christopher. 'The partition of India.' Unpublished manuscript, n.d.

Husain, S. Wajahat. 'Woman in the pond!: Reminiscences [of] Punjab Boundary Force Operations '47.' Unpublished manuscript, n.d.

\section{Published primary sources}

Bata Footwear. Advertisement. Times of India (15 August 1947), p. 4.

Batalvi, A. H., ed. The Forgotten Years: Memoirs of Muhammad Zafrullah Khan. Lahore: Vanguard, 1991.

Boggs, S. Whittemore. International Boundaries. New York: Columbia University Press, 1940.

Bowra, C. M. Memories 1898-1939. London: Weidenfeld and Nicolson, 1966.

Burrard, Sidney Gerald. Completion of the Link Connecting the Triangulations of India and Russia 1913. Dehra Dun: Trigonometrical Survey, 1914.

Campbell-Johnson, Alan. Mission with Mountbatten. New York: Atheneum, 1985.

Coldstream, W. M. Records of the Survey of India, Vol. XII: Notes on Survey of India Maps and the Modern Development of Indian Cartography. Calcutta: Survey of India, 1919.

Din Muhammad. 'Din Muhammad on Radcliffe's boundary award in the Punjab.' In Pakistan Resolution to Pakistan 1940-1947: A Selection of Documents Presenting the Case for Pakistan, ed. Latif Ahmed Sherwani, pp. 276-9. Karachi: National Publishing House, 1969.

[Gandhi, Mohandas K.] The Collected Works of Mahatma Gandhi. 90 vols. New Delhi: The Publications Division, Ministry of Information and Broadcasting, Government of India, 1979.

Godrej. Advertisement. Times of India, Supplement (15 August 1947), p. 9.

Gopal, S., ed. Selected Works of Jawaharlal Nehru. 2nd series, vol. IV. New Delhi: Jawaharlal Nehru Memorial Fund, 1986.

[Government of Punjab.] Integration of West Pakistan. Karachi: Ferozesons, [1995?].

Great Britain, House of Commons. Parliamentary Debates (Hansard). 5th series, vol. 434. London: HMSO, 1947.

—, Parliamentary Debates (Hansard). 5th series, vol. 440. London: HMSO, 1947.

Hamid, Shahid. Disastrous Twilight: A Personal Record of the Partition of 


\section{BIBLIOGRAPHY}

India by Major-General Shahid Hamid, Private Secretary to Field Marshal Sir Claude Auchinleck. Barnsley, South Yorkshire: Leo Cooper, 1986.

Hasmi, M. N. A. Survey of Pakistan Progress Report 1947 to 1961. [Karachi?]: [Survey of Pakistan?], [1961?].

Heaney, G. F. 'Preface.' In Survey of India Technical Report 1947. Dehra Dun: Survey of India, 1949.

Husain, S. Wajahat. 'The evacuation of Kapurthala state Muslims.' Dawn (14 August 1992), p. VII.

India: Bilateral Treaties and Agreements. 10 vols. New Delhi: Ministry of External Affairs, Government of India, 1994-97.

Intelligence Reports Concerning the Tribal Repercussions to the Events in the Punjab, Kashmir and India. Lahore: Superintendent Government Printing West Punjab, 1948.

Ismay, Hastings Lionel. 'India, 1947: A personal story.' United Empire (JulyAugust 1948), pp. 195-8.

- The Memoirs of General Lord Ismay. London: Heinemann, 1960.

Jones, Stephen B. Boundary-Making: A Handbook for Statesmen, Treaty Editors and Boundary Commissioners. Washington, DC: Carnegie Endowment for International Peace, 1945.

Khan, Rashid Ahmad. Map of Kasur Tahsil [map]. 1:126,720. Lahore: Kapur Art Printing Work, [n.d.]. British Library, India Office Records, L/P\&J/10/117, Map 1.

Khan, Saleem Ullah, comp. The Journey to Pakistan: A Documentation of Refugees of 1947. Islamabad: National Documentation Centre, 1993.

Khosla, G. D. Stern Reckoning: A Survey of Events Leading up to and Following the Partition of India. Oxford: Oxford University Press, 1989.

[Labour Party.] 'Let us face the future.' New York: League for Industrial Democracy, 1945.

Mahajan, Mehr Chand. Looking Back: The Autobiography of Mehr Chand Mahajan Former Chief Justice of India. London: Asia Publishing House, 1963.

Mansergh, Nicholas et al., eds. Constitutional Relations between Britain and India: The Transfer of Power 1942-7. 12 vols. London: HMSO, 1970-83.

Moon, Penderel, ed. Wavell: The Viceroy's Journal. London: Oxford University Press, 1973.

- Divide and Quit: An Eyewitness Account of the Partition of India. New ed. Delhi: Oxford University Press, 1998.

Morgan, J. Cumming. 'A labour company at Ypres.' In Everyman at War: Sixty Personal Narratives of the War, ed. C. B. Purdom, pp. 130-5. New York: E. P. Dutton, 1930.

Munir, Muhammad. Highways and Bye-Ways of Life. Lahore: Law Publishing Company, n.d. [1978].

—. From Jinnah to Zia. Lahore: Vanguard Books, 1980.

—. 'Partition of the Punjab', Times of India (19 August 1947), p. 7.

—. 'Radcliffe award announced', Pakistan Times (19 August 1947), p. 1.

Radcliffe, Cyril. The Problem of Power: The Reith Memorial Lectures 1951. London: Secker and Warburg, 1952.

—. The Law and Its Compass. London: Faber \& Faber, 1960. 


\section{BIBLIOGRAPHY}

—. [No title], The Haileyburian Centenary Magazine (1962), pp. 58-9.

- Not in Feather Beds: Some Collected Papers. London: Hamish Hamilton, 1968.

- Government by Contempt. London: Chatto and Windus, 1967.

Report on Police Administration in the Punjab for the Year 1949. Lahore: Superintendent Government Printing Punjab, 1952.

Report on Police Administration in the Punjab for the Year 1950. Lahore: Superintendent Government Printing Punjab, 1953.

Report on Police Administration in the Punjab for the Year 1951. Lahore: Superintendent Government Printing Punjab, 1953.

Report on Police Administration in the Punjab for the Year 1952. Lahore: Superintendent Government Printing Punjab, 1955.

Report on Police Administration in the Punjab for the Year 1953. Lahore: Superintendent Government Printing West Pakistan, 1957.

Report on Police Administration in the Punjab for the Year 1954. Lahore: Superintendent Government Printing West Pakistan, 1958.

Report on Police Administration in the Punjab for the Year 1955. Lahore: Superintendent Government Printing West Pakistan, 1958.

Sadullah, Mian Muhammad et al., eds The Partition of the Punjab-1947. 4 vols. Lahore: Sang-e-Meel Publications, 1993.

Sain, Kanwar. Reminiscences of an Engineer. New Delhi: Young Asia Publications, 1978.

Setalvad, Motilal C. My Life: Law and Other Things. London: Sweet \& Maxwell, 1971.

Singh, Kirpal, ed. Select Documents on Partition of Punjab - 1947: India and Pakistan: Punjab, Haryana and Himachal - India and Punjab - Pakistan. Delhi: National Book Shop, 1991.

Spate, O. H. K. 'The partition of Punjab and of Bengal.' Geographical Journal 110 (1947), pp. 201-22.

- 'The partition of India and the prospects of Pakistan.' Geographical Review 38 (1948), pp. 5-29.

- On the Margins of History: From the Punjab to Fiji. Canberra: National Centre for Development Studies, Australian National University, 1991.

Survey of Pakistan. 'Map of Pakistan showing political divisions' [map]. 2nd edn. 1:3,168,000. Murree: Survey of Pakistan, 1953.

Thyer, Donald C. 'The partition of India - A personal account.' Royal Engineers Journal 111 (December 1997), p. 263.

Tuker, Francis. While Memory Serves. London: Cassell, 1950.

Union Life Assurance. Advertisement. Times of India (Bombay) (15 August 1947), p. 3.

Wheeler, Oliver. The Survey of India during War and Early Reconstruction, 1939-1946. Dehra Dun: Survey of India, 1955.

Williams, Francis. A Prime Minister Remembers: The War and Post-War Memoirs of the Rt. Hon. Earl Attlee, Based on his Private Papers and on a Series of Recorded Conversations. London: Heinemann, 1961.

Zaidi, Z. H. et al., eds Jinnah Papers. Islamabad: Quaid-i-Azam Papers Project, 2000. 


\section{BIBLIOGRAPHY}

\section{Personal interviews}

Azim, Zarrar. Lieutenant-General, Pakistan Army; Director-General, Pakistan Rangers. Personal interview: 13 July 2000.

Beaumont, Christopher. Private secretary to Cyril Radcliffe, 1947. Personal interviews: 8 and 29 February 2000.

Husain, S. Wajahat. Major-General (Ret.), Pakistan Army; Lieutenant, Punjab Boundary Force, 1947. Personal interview: 30 July 2000.

Janjua, Adnan. Colonel, Pakistan Army; Wing Commander, Pakistan Rangers. Personal interview: 1 September 2000.

Kirmani, Ahmed Sayed. Member, Muslim League legal team, Punjab Boundary Commission, 1947. Personal interview: 3 September 2000.

Sadullah, Mian Muhammad. Superintendent, Punjab Boundary Commission, 1947. Personal interview: September 2000.

Tennant, Mark. Stepson of Cyril Radcliffe. Personal interview: 9 February 2000.

\section{Newspapers}

Pakistan Times

Times of India

\section{Secondary sources}

Ahmed, Ishtiaq. 'The 1947 partition of Punjab: Arguments put forth before the Punjab Boundary Commission by the parties involved.' In Region and Partition: Bengal, Punjab and the Partition of the Subcontinent, eds Ian Talbot and Gurharpal Singh, pp. 116-67. Oxford: Oxford University Press, 1999.

Aiyar, Swarna. "'August anarchy": The partition massacres in Punjab, 1947.' In Freedom, Trauma, Continuities: Northern India and Independence, eds D. A. Low and Howard Brasted, pp. 15-38. Walnut Creek, CA: AltaMira Press, 1998.

Ali, Imran. The Punjab under Imperialism, 1885-1947. Princeton: Princeton University Press, 1988.

Ancel, Jacques, 'Les frontières; Étude de géographie politique.' Recueil des cours 55 (1936), pp. 203-97.

Anderson, Benedict. Imagined Communities: Reflections on the Origin and Spread of Nationalism. Rev. ed. London: Verso, 1991.

Ashcroft, R. L. Haileybury, 1908-1961. N.p.: The Haileybury Society; Frome: Butler \& Tanner, 1961.

Asiwaju, Anthony. Borderlands Research: A Comparative Perspective. El Paso, TX: University of Texas at El Paso, 1983.

Auden, W. H. 'Partition.' In City without Walls and Other Poems, pp. 86-7. New York: Random House, 1969.

Aziz, Khursheed Kamal. A History of the Idea of Pakistan. 4 vols. Lahore: 


\section{BIBLIOGRAPHY}

Vanguard Books, 1987.

- The Murder of History: A Critique of History Textbooks Used in Pakistan. Lahore: Vanguard, 1993.

Banga, Indu, ed. Five Punjabi Centuries: Polity, Economy, Society and Culture, c. 1500-1990. New Delhi: Manohar, 2000.

Basu, Aparna. 'Uprooted women: Partition of Punjab 1947.' In Nation, Empire, Colony: Historicizing Gender and Race, eds Ruth Roach Pierson and Nupur Chaudhuri, with the assistance of Beth McAuley. Bloomington, IN: Indiana University Press, 1998.

Baud, Michiel and Willem van Schendel. 'Toward a comparative history of borderlands.' Journal of World History 8:2 (1997), pp. 211-42.

Bhalla, Alok, ed. Stories about the Partition of India. 3 vols. New Delhi: HarperCollins, 1994.

Birkenhead, Frederick. Walter Monckton: The Life of Viscount Monckton of Brenchley. London: Weidenfeld \& Nicolson, 1969.

Black, Jeremy. Maps and Politics. London: Reaktion Books, 1997.

Blackwell, Michael. Clinging to Grandeur: British Attitudes and Foreign Policy in the Aftermath of the Second World War. Westport, CT: Greenwood Press, 1993.

Bolitho, Hector. Jinnah: Creator of Pakistan. London: John Murray, 1954.

Bose, Pradip Kumar. 'Memory begins where history ends.' In Reflections on Partition in the East, ed. Ranabir Samaddar, pp. 73-86. New Delhi: Vikas Publishing House, 1997.

Bose, Sugata and Ayesha Jalal. Modern South Asia. London: Routledge, 1998. Boyle, Andrew. Poor, Dear Brendan: The Quest for Brendan Bracken. London: Hutchinson, 1974.

Brecher, Michael. Nehru: A Political Biography. London: Oxford University Press, 1959.

- Rev. of Last Days of the British Raj, by Leonard Mosley. Pacific Affairs 35:3 (Autumn 1962), pp. 295-6.

Briggs, Asa. History of Broadcasting in the United Kingdom. Vol. 2, The War of Words. London: Oxford University Press, 1970.

Brines, Russell. The Indo-Pakistani Conflict. London: Pall Mall Press, 1968.

Brown, Judith. Gandhi: Prisoner of Hope. New Haven: Yale University Press, 1989.

Butalia, Urvashi. 'Muslims and Hindus, men and women: Communal stereotypes and the partition of India.' In Women and Right-Wing Movements: Indian Experiences, eds Tanika Sarkar and Urvashi Butalia, pp. 58-81. London: Zed Books, 1995.

- The Other Side of Silence. New Delhi: Viking, 1998.

—. 'Community, state, and gender: Some reflections on the partition of India.' In Inventing Boundaries: Gender, Politics and the Partition of India, ed. Mushirul Hasan, pp. 178-207. New Delhi: Oxford University Press, 2000.

Cain, P. J. and Anthony Hopkins. British Imperialism: Innovation and Expansion, 1688-1914. London: Longman, 1993.

- British Imperialism: Crisis and Deconstruction, 1914-1990. London: Longman, 1993. 


\section{BIBLIOGRAPHY}

Chakrabarty, Dipesh. 'Remembered villages: Representations of Hindu-Bengali memories in the aftermath of the partition.' In Freedom, Trauma, Continuities: Northern India and Independence, eds D. A. Low and Howard Brasted, pp. 133-52. Walnut Creek, CA: AltaMira Press, 1998.

Chatterii, Joya. 'The fashioning of a frontier: The Radcliffe Line and Bengal's border landscape, 1947-1952.' Modern Asian Studies 33:1 (1999), pp. 185242.

- The Spoils of Partition: Bengal and India, 1947-1967. Cambridge: Cambridge University Press, 2007.

Chaudhri, Nazir Hussain, ed. Chief Justice Muhammad Munir: His Life, Writings and Judgments. Lahore: Research Society of Pakistan, University of the Punjab, 1973.

Chester, Lucy. 'Mapping imperial expansion: Colonial cartography in North America and South Asia.' The Portolan 45 (Fall 1999), pp. 9-24.

- 'The mapping of empire: French and British cartographies of India in the late eighteenth century.' Portuguese Studies 16 (October 2000), pp. 256-75

- 'Factors impeding the effectiveness of partition in South Asia and the Palestine mandate.' In Order, Conflict, and Violence, eds Stathis N. Kalyvas, Ian Shapiro and Tarek Masoud, pp. 75-96. Cambridge: Cambridge University Press, 2008.

Cohn, Bernard. 'The census, social structure and objectification in South Asia.' In An Anthropologist among the Historians and Other Essays. Delhi: Oxford University Press, 1987.

Collins, Larry and Dominique Lapierre. Freedom at Midnight. New York: Simon and Schuster, 1975.

—. Mountbatten and Independent India. 3rd edn. New Delhi: Vikas Publishing House, 1989.

- Mountbatten and the Partition of India. New Delhi: Vikas Publishing House, 1999.

Copland, Ian. 'The further shores of partition: Ethnic cleansing in Rajasthan 1947.' Past et) Present 160 (1998), pp. 203-39.

Coupland, Reginald. The Indian Problem: Report on the Constitutional Problem in India. New York: Oxford University Press, 1944.

Das, Veena. 'National honour and practical kinship: Of unwanted women and children.' In Critical Events: An Anthropological Perspective on Contemporary India. Delhi: Oxford University Press, 1995.

- ' 'Official narratives, rumour, and the social production of hate.' Social Identities 4:1 (1998), pp. 109-30.

Donnan, Hastings and Thomas M. Wilson. Borders: Frontiers of Identity, Nation and State. Oxford: Berg, 1999.

Edney, Matthew. Mapping an Empire: The Geographical Construction of British India, 1765-1843. Chicago: University of Chicago Press, 1997.

Edwardes, Michael. The Last Years of British India. Cleveland: World Publishing Company, 1963.

- Nehru: A Political Biography. New York: Praeger Publishers, 1971.

Ellis, Roger. 'Abell, Sir George Edmond Brackenbury (1904-1989).' Rev. Oxford 


\section{BIBLIOGRAPHY}

Dictionary of National Biography. Oxford: Oxford University Press, 2004. www.oxforddnb.com/view/article/39894. Accessed 29 February 2008.

Embree, Ainslie T., ed. Pakistan's Western Borderlands: The Transformation of a Political Order. Durham, NC: Carolina Academic Press, 1977.

—. 'Frontiers into boundaries: The evolution of the modern state.' In Imagining India: Essays on Indian History, ed. Mark Juergensmeyer, pp. 67-84. Delhi: Oxford University Press, 1989.

Fay, Peter Ward. The Forgotten Army: India's Armed Struggle for Independence 1942-1945. Ann Arbor: University of Michigan Press, 1993.

Ferguson, Niall, ed. Virtual History: Alternatives and Counterfactuals. London: Picador, 1997.

French, Patrick. Liberty or Death. London: HarperCollins, 1997.

Gilmartin, David. Empire and Islam: Punjab and the Making of Pakistan. Berkeley: University of California Press, 1988.

- 'Scientific empire and imperial science: Colonialism and irrigation technology in the Indus basin.' Journal of Asian Studies 53:4 (November 1994), pp. 1127-49.

—. 'Partition, Pakistan, and South Asian history: In search of a narrative', Journal of Asian Studies 57:4 (November 1998), pp. 1068-95.

Goethals, Helen. 'Poetry and history in the context of W. H. Auden's poem "Partition"'. Paper delivered at the fourth meeting of the Société AngloIndienne et Histoire de l'Inde Britannique et Contemporaine, 'La route des Indes', 3-4 September 1999.

Goldenberg, Suzanne. 'Memories of Mountbatten.' Guardian (7 August 1997), p. 3.

Gole, Susan. Early Maps of India. New York: Humanities Press, 1976.

—. India within the Ganges. New Delhi: Jayaprints, 1983.

- Indian Maps and Plans. New Delhi: Manohar Publications, 1989.

[Government of India.] 'Border Security Force.' http://bsf.nic.in/introduction. htm. Accessed 29 February 2008.

[Government of Pakistan.] 'Pakistan Rangers (Punjab).' www.pak.gov.pk/ public/govt/reports/punjab_rangers.htm.

Grewal, J. S. and Indu Banga, eds Punjab in Prosperity and Violence: Administration, Politics and Social Change 1947-1997. Chandigarh: Institute of Punjab Studies, 1998.

Hansen, Anders Bjørn. Partition and Genocide: Manifestation of Violence in Punjab 1937-1947. New Delhi: India Research Press, 2002.

Harley, John Brian. The New Nature of Maps. Baltimore: Johns Hopkins University Press, 2001.

Hasan, Mushirul, ed. India's Partition: Process, Strategy and Mobilization. Delhi: Oxford University Press, 1993.

- ed. India Partitioned: The Other Face of Freedom. 2 vols. New Delhi: Roli Books, 1995.

- Inventing Boundaries: Gender, Politics, and the Partition of India. New Delhi: Oxford University Press, 2000.

Hayden, Robert. 'Schindler's fate: Genocide, ethnic cleansing, and population transfers.' Slavic Review 55:4 (Winter 1996), p. 739. 


\section{BIBLIOGRAPHY}

Hennessy, Peter. 'The eternal fireman.' The Times (London) (30 January 1976), p. 16 .

- Whitehall. London: Fontana Press, 1990.

Herschy, Reg. Disputed Frontiers. Lewes, Sussex: Book Guild, 1993.

Heward, Edmund. The Great and the Good: A Life of Lord Radcliffe. Chichester: Barry Rose Publishers, 1994.

Hodson, H. V. The Great Divide: Britain - India - Pakistan. 1969. Jubilee Series ed. Karachi: Oxford University Press, 1997.

Howarth, T. E. B. Prospect and Reality: Great Britain 1945-1955. London: Collins, 1985.

Human Rights Watch. 'Recent landmine use by India and Pakistan.' May 2002. www.hrw.org//backgrounder/arms/ind-pak-landmines.htm. Accessed 3 March 2008.

'India before partition.' [map]. 1:15,840,000. In The Transfer of Power 1942-7. Vol. XII, eds Nicholas Mansergh and Penderel Moon. London: HMSO, 1983.

International Campaign to Ban Landmines. 'Landmine Monitor Report 2005: India.' October 2005. www.icbl.org/lm/2005/india. Accessed 12 June 2008.

Islam, M. Mufakharul. Irrigation, Agriculture and the Raj: Punjab, 1887-1947. New Delhi: Manohar, 1997.

Jalal, Ayesha. The Sole Spokesman. Cambridge: Cambridge University Press, 1985.

- Self and Sovereignty: Individual and Community in South Asian Islam Since 1850. New Delhi: Oxford University Press, 2001.

Jeffrey, Robin. 'The Punjab Boundary Force and the problem of order, August 1947.' Modern Asian Studies 8:4 (1974), pp. 491-520.

Kalra, Virinder S. and Navtej K. Purewal. 'The strut of the peacocks: Partition, travel and the Indo-Pak border.' In Travel Worlds: Journeys in Contemporary Cultural Politics, eds Raminder Kaur and John Hutnyk, pp. 54-67. London: Zed Books, 1999.

Kamtekar, Indivar. 'The military ingredient of communal violence in Punjab, 1947.' Abstracts of Sikh Studies 4:1 (2002), pp. 48-52.

Kant, Surya. Administrative Geography of India. Jaipur: Rawat Publications, 1988.

Kaufmann, Chaim. 'Possible and impossible solutions to ethnic civil wars.' International Security 20:4 (Spring 1996), p. 137.

Kent, John. 'Bevin's imperialism and Euro-Africa, 1945-49.' In British Foreign Policy, 1945-56, eds Michael Dockrill and John Young, pp. 47-76. New York: St Martin's Press, 1989.

Khan, Nighat Said. 'Identity, violence and women: A reflection on the partition of India 1947.' In Locating the Self: Perspectives on Women and Multiple Identities, eds Nighat Said Khan, Rubina Saigol and Afiya Shehrbano Zia, pp. 157-71. Lahore: ASR Publications, 1994.

Khan, Yasmin. The Great Partition: The Making of India and Pakistan. New Haven: Yale University Press, 2007.

Khilnani, Sunil. The Idea of India. London: Hamish Hamilton, 1997.

—. 'India's mapmaker.' Observer (London) (22 June 1997), p. 7. 


\section{BIBLIOGRAPHY}

Krishna, B. Sardar Vallabhbhai Patel: India's Iron Man. New Delhi: HarperCollins, 1996.

Kudaisya, Gyanesh. 'From displacement to "development": East Punjab countryside after partition, 1947-67.' In Freedom, Trauma, Continuities: Northern India and Independence, eds D. A. Low and Howard Brasted, pp. 73-90. Walnut Creek, CA: AltaMira Press, 1998.

Kumar, Radha. Divide and Fall? London: Verso, 1997.

Lamb, Alastair. Letter. Daily Telegraph (25 February 1992), p. 16.

—. Birth of a Tragedy: Kashmir 1947. Hertingfordbury: Roxford Books, 1994.

- Incomplete Partition: The Genesis of the Kashmir Dispute 1947-1948. Hertingfordbury: Roxford Books, 1997.

Lapierre, Dominique. A Thousand Suns: Witness to History. New York: Warner Books, 1999.

Louis, Wm. Roger. The British Empire in the Middle East, 1945-1951. Oxford: Clarendon Press, 1984.

Lysaght, Charles. Brendan Bracken. London: Allen Lane, 1979.

Madan, P. L. Indian Cartography: A Historical Perspective. New Delhi: Manohar, 1997.

Mahajan, Vidya Dhar. Chief Justice Mehr Chand Mahajan (The Biography of the Great Jurist). Lucknow: Eastern Book Company, 1969.

Major, Andrew J. "'The chief sufferers": Abduction of women during the partition of the Punjab.' In Freedom, Trauma, Continuities: Northern India and Independence, eds D. A. Low and Howard Brasted, pp. 57-72. Walnut Creek, CA: AltaMira Press, 1998.

Manto, Saadat Hasan. Mottled Dawn: Fifty Sketches and Stories of Partition. New Delhi: Penguin, 1997.

Martinez, Oscar J. Border People: Life and Society in the U.S.-Mexico Borderlands. Tucson: University of Arizona Press, 1994.

Mayaram, Shail. 'Speech, silence and the making of partition violence in Mewat.' In Subaltern Studies IX: Writings on South Asian History and Society, eds Shahid Amin and Dipesh Chakrabarty, pp. 126-64. Delhi: Oxford University Press, 1996.

Menon, Ritu. 'Reproducing the legitimate community: Secularity, sexuality, and the state in postpartition India.' In Appropriating Gender: Women's Activism and Politicized Religion in South Asia, eds Patricia Jeffery and Amrita Basu, pp. 15-32. New York: Routledge, 1998.

Menon, Ritu and Kamla Bhasin. Borders and Boundaries: Women in India's Partition. New Brunswick, NJ: Rutgers University Press, 1998.

- 'Recovery, rupture, resistance: The Indian state and the abduction of women during partition.' In Inventing Boundaries: Gender, Politics and the Partition of India, ed. Mushirul Hasan, pp. 208-35. New Delhi: Oxford University Press, 2000.

Metcalf, Barbara D. and Thomas R. Metcalf. A Concise History of India. Cambridge: Cambridge University Press, 2002.

Metcalf, Thomas. Ideologies of the Raj. Cambridge: Cambridge University Press, 1995. 


\section{BIBLIOGRAPHY}

Michel, Aloys. The Indus Rivers: A Study of the Effects of Partition. New Haven: Yale University Press, 1967.

Mishra, Prabhakar. 'Cadastral surveys in India - A critique.' GISDevelopment, n.d. www.gisdevelopment.net/application/lis/policy/lisp0001.htm. Accessed 3 March 2008.

Moore, Robin J. Escape from Empire: The Attlee Government and the Indian Problem. Oxford: Clarendon Press, 1983.

—. 'India in the 1940s.' In Oxford History of the British Empire, ed. Robin W. Winks. Vol. V. Oxford: Oxford University Press, 1999.

Morris-Jones, W. H. Rev. of Last Days of the British Raj, by Leonard Mosley. Journal of Modern History 35:2 (June 1963), pp. 223-4.

- 'Thirty-six years later: The mixed legacies of Mountbatten's transfer of power.' International Affairs 59:4 (Autumn 1983), pp. 621-8.

Mosley, Leonard. The Last Days of the British Raj. New York: Harcourt, Brace \& World, 1962.

Murphy, Richard McGill. 'Performing partition in Lahore.' In The Partitions of Memory: The Afterlife of the Division of India, ed. Suvir Kaul, pp. 183-207. Delhi: Permanent Black, 2001.

Noorani, A. G. 'Ayodhya in reverse.' Frontline 18:3 (3-16 February 2001). www.flonnet.com/fl1803/18030890.htm. Accessed 3 March 2008.

Noyes, Hugh. "'D" Notice white paper savaged: Scathing attack by Lord Radcliffe.' The Times (London) (7 July 1967), pp. 1, 5.

'Old journeys revisited', The Economist (12 February 2000), pp. 86-8.

Pandey, Gyan. 'The prose of otherness.' In Subaltern Studies VIII, eds David Arnold and David Hardiman, pp. 188-221. Delhi: Oxford University Press, 1994.

- Remembering Partition: Violence, Nationalism and History in India. Cambridge: Cambridge University Press, 2001.

'Partition boundaries in the Punjab' [map]. Approximately 1:2,661,120. September 1948. In The Transfer of Power 1942-7, Vol. XII, eds Nicholas Mansergh, Nicholas and Penderel Moon. London: HMSO, 1983.

Pelling, Henry. The Labour Governments, 1945-51. London: Macmillan Press, 1984.

Philips, C. H. and Mary Doreen Wainwright. The Partition of India: Policies and Perspectives, 1935-1947. London: Allen \& Unwin, 1970.

Plummer, Simon Scott. 'How Mountbatten bent the rules and the Indian border.' Daily Telegraph (24 February 1992), p. 10.

Potter, David. India's Political Administrators 1919-1983. Oxford: Clarendon Press, 1986.

Prescott, J. R. V. Boundaries and Frontiers. London: Croom Helm, 1978.

- Political Frontiers and Boundaries. London: Allen \& Unwin, 1987.

Rai, Satya. Partition of the Punjab: A Study of its Effects on the Politics and Administration of the Punjab (I) 1947-56. Bombay: Asia Publishing House, 1965.

Roberts, Andrew. 'Lord Mountbatten and the perils of adrenalin.' In Eminent Churchillians. London: Phoenix, 1994.

Roper, William. The Life of Sir Thomas More. London: Folio Society, 1980. 


\section{BIBLIOGRAPHY}

Roth, Andrew. 'On the Sikh-Moslem Frontier.' Nation 165:12 (20 September 1947), p. 282.

Rothschild, Nathaniel Mayer Victor. Random Variables. London: Collins, 1984.

Rushdie, Salman. Midnight's Children. New York: Knopf, 1981.

Sahlins, Peter. Boundaries: The Making of France and Spain in the Pyrenees. Berkeley: University of California Press, 1989.

Schendel, Willem van. 'Easy come, easy go: Smugglers on the Ganges.' Journal of Contemporary Asia 23:2 (1993), pp. 189-213.

- 'Working through partition: Making a living in the Bengal borderlands.' International Review of Social History 46 (2001), pp. 393-421.

- The Bengal Borderland: Beyond State and Nation in South Asia. London: Anthem Press, 2005.

Schofield, Victoria. Wavell: Soldier and Statesman. London: John Murray, 2006.

Sengupta, Somini. 'With wrath and wire, India builds a great wall.' New York Times (2 January 2002), Sec. A, p. 1, col. 1.

Sidhwa, Bapsi. Ice-Candy-Man. New Delhi: Penguin, 1988.

Singh, Darbara. 'Justice Teja Singh.' In Ten Eminent Sikhs. Amritsar: Literature House, 1982.

Singh, Gurdit and Carol C. Fair. 'The partition of Punjab: Its impact upon Sikh sacred and cultural space.' In Region and Partition: Bengal, Punjab and the Partition of the Subcontinent, eds Ian Talbot and Gurharpal Singh, pp. 253-68. Oxford: Oxford University Press, 1999.

Singh, Khushwant. A History of the Sikhs. Vol. 2. Princeton: Princeton University Press, 1966.

- Train to Pakistan. New York: Grove Press, 1990.

Spear, Percival. 'Britain's transfer of power in India.' Pacific Affairs 31:2 (June 1958), pp. 173-80.

Sukhwal, B. L. India: A Political Geography. Bombay: Allied Publishers, 1971.

Talbot, Ian. Freedom's Cry: The Popular Dimension in the Pakistan Movement and Partition Experience in North-West India. Karachi: Oxford University Press, 1996.

- Khizr Tiwana, the Punjab Unionist Party and the Partition of India. Richmond: Curzon Press, 1996.

- 'Literature and the human drama of the 1947 partition.' In Region and Partition: Bengal, Punjab and the Partition of the Subcontinent, eds Ian Talbot and Gurharpal Singh, pp. 228-52. Oxford: Oxford University Press, 1999.

- Divided Cities: Partition and Its Aftermath in Lahore and Amritsar 1947-1957. Oxford: Oxford University Press, 2006.

Tan Tai Yong. "'Sir Cyril goes to India": Partition, boundary-making and disruptions in the Punjab.' International Journal of Punjab Studies 4:1 (1997), pp. 1-20.

- The Garrison State: Military, Government and Society in Colonial Punjab, 1849-1947. New Delhi: Sage Publications, 2005. 


\section{BIBLIOGRAPHY}

Tan Tai Yong and Gyanesh Kudaisya. The Aftermath of Partition in South Asia. London: Routledge, 2000.

Tanwar, Raghuvendra. Reporting the Partition: Press, Public, and Other Opinions. New Delhi: Manohar, 2006.

Thandi, Shinder S. 'The unidentical Punjab twins: Some explanations of comparative agricultural performance since partition.' In Region and Partition: Bengal, Punjab and the Partition of the Subcontinent, eds Ian Talbot and Gurharpal Singh, pp. 298-324. Oxford: Oxford University Press, 1999.

Tinker, Hugh. Experiment with Freedom: India and Pakistan, 1947. London: Oxford University Press, 1967.

- 'Pressure, persuasion, decision: Factors in the partition of the Punjab, August 1947.' Journal of Asian Studies 36:4 (August 1977), p. 695.

Tufte, Edward. Envisioning Information. Cheshire, CT: Graphics Press, 1990.

- Visual Explanations: Images and Quantities, Evidence and Narrative. Cheshire, CT: Graphics Press, 1997.

- The Visual Display of Quantitative Information. 2nd ed. Cheshire, CT: Graphics Press, 2001.

United States Army Map Service. NH 43-6, 'Ferozepore' [map]. Edition 1-AMS. 1:250,000. Series U502. Washington: Army Map Service, 1959.

—. NH 43-2, 'Lahore' [map]. Edition 2-AMS. 1:250,000. Series U502. Washington: Army Map Service, 1963.

Venkataramani, M. S. and B. K. Shrivastava. Roosevelt-Gandhi-Churchill: America and the Last Phase of India's Freedom Struggle. New Delhi: Radiant Publishers, 1983.

von Tunzelmann, Alex. Indian Summer: The Secret History of the End of an Empire. New York: Henry Holt and Company, 2007.

Waseem, Mohammad. 'Partition, migration and assimilation: A comparative study of Pakistani Punjab.' In Region and Partition: Bengal, Punjab and the Partition of the Subcontinent, eds Ian Talbot and Gurharpal Singh, pp. 203-27. Oxford: Oxford University Press, 1999.

Whyte, Brendan. Waiting for the Esquimo: An Historical and Documentary Study of the Cooch Behar Enclaves of India and Bangladesh. Vol. 8, Research Papers of the School of Anthropology, Geography and Environmental Studies. Melbourne: University of Melbourne, 2002.

Wilson, Thomas M. and Hastings Donnan, eds. Border Identities: Nation and State at International Frontiers. Cambridge: Cambridge University Press, 1998.

Winichakul, Thongchai. Siam Mapped: A History of the Geo-Body of a Nation. Honolulu: University of Hawaii Press, 1994.

Wolpert, Stanley. A New History of India, 3rd ed. New York: Oxford University Press, 1989.

- Shameful Flight: The Last Years of the British Empire in India. Oxford: Oxford University Press, 2006.

Woodruff, Philip [Philip Mason]. The Men Who Ruled India: The Guardians. Vol. 2. New York: St Martin's Press, 1954.

Xydis, Stephen George. Cyprus: Conflict and Conciliation, 1954-1958. Columbus: Ohio State University Press, 1967. 


\section{BIBLIOGRAPHY}

Young, Kenneth, ed. The Diaries of Sir Robert Bruce Lockhart. Vol. 2. London: Macmillan London Limited, 1980.

Zafar, Rukhsana, comp. Disturbances in the Punjab 1947. Islamabad: National Documentation Centre, 1995.

Zaminder, Vazira Fazila-Yacoobali. The Long Partition and the Making of Modern South Asia: Refugees, Boundaries, Histories. New York: Columbia University Press, 2007.

Ziegler, Philip. Mountbatten: The Official Biography. New York: Harper \& Row, 1985.

- Mountbatten Revisited. Austin, TX: Harry Ransom Humanities Research Center, The University of Texas at Austin, 1995.

\section{Unpublished theses}

Aiyar, Swarna. 'Violence and the State in the Partition of Punjab: 1947-48.' Unpublished Ph.D dissertation, University of Cambridge, 1994.

Hasan, Masuma. 'The Transfer of Power to Pakistan and Its Consequences.' Unpublished Ph.D dissertation, University of Cambridge, 1967. 